\title{
An Analysis of Primary School Teachers Characters Learning Process on Teaching Model Development Named Open Ended Approach-based Advance Organizer on Students Reasoning Skill
}

\author{
Joko Sulianto*, Sunardi, Sri Anitah, Gunarhadi \\ Department of Educational Science, Faculty of Teacher Training and Education, Sebelas Maret University, Indonesia
}

Received December 9,2019; Revised February 17, 2020; Accepted February 25, 2020

Copyright $@ 2020$ by authors, all rights reserved. Authors agree that this article remains permanently open access under the terms of the Creative Commons Attribution License 4.0 International License

\begin{abstract}
The aim of this study is to describe the teaching and learning process on primary school in Semarang. Qualitative approach is chosen. The subjects of this study are Primary school classroom teacher on Semarang. The data was taken through questionnaire and observation sheet. Based on the research data, it is shown that learning process aspect was $79.22 \%$ (fair), scientific approach was $75.51 \%$ (fair), open-ended approach was $74.28 \%$ (fair), and students reasoning aspect was 68.31 (adequate). In the aspect of reasoning students show sufficient criteria meaning that the ability of students in connecting facts to develop arguments to obtain conclusions or new knowledge is still low. Data shows aspects of student reasoning still need to be improved so it is necessary to develop a learning model to improve aspects of student reasoning in primary schools.
\end{abstract}

Keywords Students Reasoning Skill, Primary School Teachers, Learning Process

\section{Introduction}

Education takes an important place in developing human intellectuality that are able to: 1) do technological literacy, 2) make an effective communication, 3) think critically, 4) solve the problems, and 5) collaborate with other. These abilities are related to the implementation of School-based Curriculum 2013 that support teaching process on Information and Communication Technology (ICT). It brings positive atmosphere in education only if the people could put technology in increasing educational quality (Kemendikbud, 2013; 2015).
Human changing characters give impact to teacher characters on teaching process. They must empower teachers' main position as the facilitators. Discussing, problem solving, thinking critically must be done regularly. The paradigm change teachers' point of view from teacher-centre to student-centre. They must be more creative and innovative in developing several teaching method and able to solve educational problems.

The millennial must have these following categories: 1) thinking critically and solving problems, 2) mastering digital literacy (ICT and latest media), 3) having live and carrier ability included flexible and adaptive skills, social culture skills, productive and countable leadership, and responsibility. In the 21st century, what is demanded is the characteristics of students who have learning and innovation skills, that is, supporting critical thinking skills. Critical thinking requires reasoning, (Brodie, 2010; Schunk, 2012; Fisher, 2009, Shadiq, 2004, and Kroll, 2016) reasoning is an activity of thinking in developing arguments to convince others of certain agreements or to solve problems or to integrate ideas in solving problems. A research conducted by Kusumawardani, (2018) shows that the ability of reasoning increases students' mathematical literacy ability by giving assignments, so students use the ability of reasoning to help the tasks needed then increasing the ability of mathematical literacy to increase.

The aim of this study is to describe the teaching and learning process on primary school in Semarang. Ministry of Education states that learning process is a process among students, among teacher, and some educational sources.

Kemendikbud (2014; 2016) states that learning is a process of interaction between students and between students and educators and learning resources in a learning 
environment. The learning process must be done in fun, attractive, interactive, and motivate the student to take active participation, give space to be more independent and support their talent, physical and psychological students' development.

Those principles which are used on School-based Curriculum 2013 that support Advance Organizer Open ended-based are as follows: (1) from student-to-know being student-to-understand, (2) from teacher-centre being several teaching sources, (3) from textual approach being process as empower scientific approach, (4) from content-based to competence-based learning, and (5) single answer learning to multidimensional answer (kemendikbud, 2014; 2016).

Curriculum 2013 has been done on primary schools. The concept of Curriculum 2013 that is students are able to reason and understand a given question, not only answer question correctly.

On Mathematics field, to reach the goal of learning process on $21^{\text {st }}$ century which is thinking critically, solving problem, and creating innovative learning process, reasoning aspect is important to help students giving their opinion and making decision skill. A teaching model is needed to be developed to support these skills.

This study discusses about Advance Organizerteaching modelusing Open Ended-approach to enhance students' reasoning skill. It is because the students can manage their knowledge, process new information, investigate their own strategies, and elaborate problem (Dell'Ollio, 2007; Joyce \& Weil, 2011). By then, hopefully, primary students can get their own reasoning skill.

The importance of this study is to describe primary school students learning characters and to push their reasoning skill. These give the teachers an idea to do interactive, attractive, challenging, and also can motivate students to take part on their class.

\section{Method}

\subsection{Research Design}

This study uses the Research and Development (R \&D) method. It is a process to develop a new product or to complete the previous product in high responsibility (Gall, Gall \& Borg, 2007; Borg \& Gall, 1983; Sukmadinata, 2012). In another word, Setyosari (2012: 214) states that $R$ $\& D$ is a process to develop and valid educational tools. Sukmadinata (2012: 167) states that descriptive, evaluative, and experimental methods can be used to conduct R \& D.

Here are three steps in conducting this study: 1) Previous Study. It begins with a descriptive qualitative approach about related literature, field study, and description of the developed product (Creswell, 2012; 2016). The purpose is to catch the determination on developing a product; 2) Developing Stage. It consists of: developing product design, creating product prototype, and product test; 3) Product Trial and Error. In this last step aims to show that new developed product is better than the previous one. It also means to measure the new developed product. (Suwandi, 2016: 39).

\subsection{Research Procedure}

The study had been conducted in two steps:

a) Planning, teaching and learning process, reasoning aspect, and teaching approach conduct in Semarang on March to April 2017. There were 28 primary school teachers toke part as the respondents in this study. The objectives of this study were to know the planning of learning process, the learning process, the way of teaching, and reasoning aspect of the students.

b) The next previous study was conducted by giving questionnaire toward 45 teachers and principals in Semarang related to the implementation of SBC 2013 and the importance of developing teaching model to enhance students' reasoning skill, analyses standard process of teaching, and standard of competence. The study was conducted in Semarang.

\subsection{Instrument and Data Analysis}

Scoring used in the questionnaire consists of five scores, namely a score of 5: Very Good; Score 4: Good; Score 3: Good Enough; Score 2: Poor; and score 1: Not Good. The five scores used are commonly called the Likert Scale, which aims to measure the attitudes and opinions given by respondents. With this Likert scale, respondents were asked to complete a questionnaire that required them to indicate their level of agreement with a series of questions. The results of students' responses were then analyzed by using descriptive statistics using Microsoft Excel. The criteria used are presented in Table 1.

Table 1. Criteria used in research

\begin{tabular}{|c|c|c|}
\hline No & Range (\%) & Criteria \\
\hline 1 & $0-20$ & Not good \\
\hline 2 & $21-40$ & Not good \\
\hline 3 & $41-60$ & Adequate \\
\hline 4 & $61-80$ & Fair \\
\hline 5 & $81-100$ & Very good \\
\hline
\end{tabular}

\section{Results and Discussion}

The data mention in this article was taken from the previous study about learning characters in primary school to develop Open Ended-based Advance Organizer to enhance students' reasoning skills. The result of the implementation of the learning aspect, scientific approach, open-ended approach, and reasoning students' skill mentioned in this following Table 2. 
Table 2. Research Result

\begin{tabular}{|c|c|c|c|c|}
\hline & Learning Aspect & Scientific Approach Aspect & Open Ended Approach Aspect & Reasoning Aspect \\
\hline Mean & 99,03571 & 26,42857 & 29,71429 & 47,82143 \\
\hline Maximum Score & 125 & 35 & 40 & 70 \\
\hline Persentage (\%) & 79,22857 & 75,5102 & 74,28571 & 68,31633 \\
\hline Criteria & Fair & Fair & Fair & Adequate \\
\hline
\end{tabular}

As mentioned on Table 2, learning aspect was categorized fairly with achievement $72.22 \%$. The indicators were: teaching preparation, designing lesson plan, creating subject lesson, giving dynamic questions, delivering objectives of the lesson, giving student mastery, reminding previous material and the following material, giving concept and its criteria from the simple to the complex, asking for students participation related to their own understanding, using child-friendly illustration media, giving direction and explanation of topic today, delivering today's lesson, getting students' attention, facilitating students to learn meaningful material by giving correct and incorrect example, facilitating students on exploration, elaboration and confirmation, delivering lesson through presentation, discussion, and reading books, reviewing today's lesson, building interactive class by opening and responding questions, giving material in logic, clear, and coherent ways, connecting teaching material and relevant information, and keeping positive and active interaction in learning process between teacher and students. Namira, Z. B., Kusumo, E., \& Prasetya, A. T. (2014). Advance Organizer's assisted metacognitive strategies are proven effective in improving student learning outcomes at school.

Rahayu and Supartono (2010) state that the development of advance organizer model can increase students' activities and report, while Sajadi, et al (2013) and Shabania, Mardiati \&\& Sofyan (2015) state that students who were able to represent will be easy to understand assignments and solving problems on Biology subject matter.

From these indicators, there were several aspects that needed to be improved. It was making summary of today’s lesson together with students.

As mentioned on Table 2, Scientific Approach Aspect was categories Fair with achievement 75,5102\%. The indicators were: asking questions "why" and "how", delivering illustration that make students asking questions, facilitating students to observe, facilitating active students by analyzing, asking question to her/him to build critical thinking, and interacting active communication. From these indicators, here is a thing to be developed; it is facilitating students to think critically.

Open ended approach as mentioned on Table 2 showed that it was on Fair criteria with achievement $74.285 \%$. The indicators were: the question given got various correct answer; problems given got several solutions; problem solving oriented on process; problems given to students to get the illustration of how they solve their problems; starting the lesson by giving problem to them; teaching and learning process conducted by giving problem solving; giving chance to students think freely and critically; problems were given on real situation that can be observed and analyzed.

From these indicators, open ended aspect was conducted well. Research conducted by Fatah, et al (2016) by applying an open-ended approach can improve mathematical creative thinking skills (KBKM) and self-esteem (SE) in mathematics in high school students in terms of school categories. One approach to learning that can foster students' mathematical creativity is the open ended approach. The open ended approach based on Shimada and Becker (1997) is believed to provide more opportunities for students to gain more knowledge, experience discovery, recognize and solve problems because this approach has a wide variety of correct answers and ways of solving. Novak (2002) the construction and reconstruction of meaning by students requires that they actively seek to integrate new knowledge with knowledge that is already in their cognitive structures.

Tasiwan (2014) conducted a study that showed a result that students were able to describe, categorize, identify, formulate statement, building and analyzing concept increased their analysis and synthesis abilities. (Triwibowo, et al, 2017). It shows that students could use Treffinger teaching model open-ended approach had been done. While Pratitis and Binadja (2014) states that advance organizer teaching model (SETS) take positive effect to students' concept achievement.

Students' reasoning skill as mentioned on Table 2 was categorized adequate with achievement 68,316\%. The indicators were: explaining the definition of a concept, giving a sample of concept not only the example, mentioning characteristics of a learning concept, identifying factual data accurately, building mathematics model in solving a problem, choosing some strategies to solve problems, relating facts with procedures in analyzing material accurately, giving opinion to answer question, arranging and testing solution, solving problems based on procedure, giving opinion and presenting it, giving argument of a problem based on procedure, and concluding and giving logical argument. From these indicators, there was an activity that was in good level; they were explaining definition of a concept of learning, identifying characters or facts accurately, giving opinion to answer question, and 
concluding and giving logical argument.

Students' high thinking critically and creativity would increase by using advance organizer model. (Pamungkas, 2016). While Putra (2018) on his study showed that advance organizer model could increase students' mathematics communication.

Parjayanti (2013) states that inquiry learning and using Advance Organizer learning are effective for students 'mathematical reasoning, and Advance Organizer learning is more effective for students' mathematical reasoning than Inquiry learning. Baig \& Halai (2006) state that there are two important factors that enable students to learn rules by reasoning: The teacher asks and provides opportunities for students to explain thinking; and provide opportunities for students to engage with concrete and semi-concrete objects

The researchers shared questionnaire to 45 teachers as respondents. The results were as follows.
1. All schools inSemarang has applied Curriculum 2013.

2. All respondents understand the concept of implementing Curriculum 2013.

A respondent (code: R10) responded that the concept of application of Curriculum 2013 was the student able to understand basic concept of material, not only answering question correctly. Here is the result of questionnaire given to the respondents.

As showed on Table 3, all schools have applied Curriculum 2013 well. Teachers' understanding of Curriculum 2013 was good. Students centre learning was being applied proportionally.

The next question was about the learning process should be done. the response from respondents were as follows.

Table 3. Response from Respondents about Implementation of Curriculum 2013

\begin{tabular}{|c|c|c|c|c|}
\hline Question & R7 & $\mathbf{R 8}$ & R9 & R14 \\
\hline $\begin{array}{l}\text { How is the } \\
\text { implementation of } \\
\text { learning process of } \\
\text { Curriculum 2013? }\end{array}$ & $\begin{array}{l}\text { It supports students to } \\
\text { be active on teaching } \\
\text { learning process so they } \\
\text { will get new learning } \\
\text { experiences. }\end{array}$ & $\begin{array}{l}\text { Learning process } \\
\text { using Curriculum } \\
2013 \text { is attractive. } \\
\text { Students are asked to } \\
\text { participate actively. }\end{array}$ & $\begin{array}{l}\text { Implementation of Curriculum } \\
\text { 2013using scientific approach, } \\
\text { so the students are more active; } \\
\text { teacher's position is the } \\
\text { facilitator and motivator. }\end{array}$ & $\begin{array}{l}\text { Learning process is held } \\
\text { in interactive, attractive, } \\
\text { and fun activities. These } \\
\text { will make the students } \\
\text { participate actively. }\end{array}$ \\
\hline
\end{tabular}

As showed on Table 3, all schools have applied Curriculum 2013 well. Teachers' understanding of Curriculum 2013 was good. Students centre learning was being applied proportionally.

The next question was about the learning process should be done. the response from respondents were as follows.

Table 4. Learning Concept

\begin{tabular}{|l|l|l|l|l|}
\hline \multicolumn{1}{|c|}{ Question } & \multicolumn{1}{|c|}{ R2 } & \multicolumn{1}{c|}{ R4 } & \multicolumn{1}{c|}{ R7 } & \multicolumn{1}{c|}{ R8 } \\
\hline $\begin{array}{l}\text { How is the learning } \\
\text { process should be } \\
\text { done? }\end{array}$ & $\begin{array}{l}\text { Learning process must be } \\
\text { focused on students; teachers } \\
\text { are facilitator to break problem, } \\
\text { or as problem solver. }\end{array}$ & $\begin{array}{l}\text { Learning process } \\
\text { must be done to } \\
\text { support students' } \\
\text { reason skill. }\end{array}$ & $\begin{array}{l}\text { Learning process must } \\
\text { be done on students' } \\
\text { center, while teachers } \\
\text { are facilitators. }\end{array}$ & $\begin{array}{l}\text { Learning process should } \\
\text { facilitate students to explore } \\
\text { their understanding that } \\
\text { make it memorable. }\end{array}$ \\
\hline
\end{tabular}

Teachers' understanding of learning activity was good. Students were the center learning and teachers as the facilitator had been done proportionally. Learning process should give chance students to solve problems and to get to know their surrounding themselves.

Table 5. Learning Model

\begin{tabular}{|c|c|c|c|c|}
\hline Question & R1 & R2 & R7 & R8 \\
\hline $\begin{array}{l}\text { What Learning } \\
\text { Model do you } \\
\text { expect? }\end{array}$ & $\begin{array}{l}\text { Which can be applied to } \\
\text { students properly, easy to } \\
\text { implement but has a } \\
\text { realistic impact on the } \\
\text { needs of students }\end{array}$ & $\begin{array}{l}\text { Learning models that really } \\
\text { provide opportunities for } \\
\text { students to express ideas, ideas } \\
\text { and opinions that train students } \\
\text { to think critically and logically. }\end{array}$ & $\begin{array}{l}\text { Learning models that are } \\
\text { able to improve students' } \\
\text { reasoning ability, dare to } \\
\text { think pleasant and easily } \\
\text { realized for teachers. }\end{array}$ & $\begin{array}{l}\text { A learning model that is } \\
\text { simple, fun, builds } \\
\text { students' habits for } \\
\text { thinking and reasoning, is } \\
\text { active in learning. }\end{array}$ \\
\hline
\end{tabular}


From the data above, it shows that the development of the model expected by the teacher is an easy learning model in its implementation, a model that provides opportunities for students to express ideas or ideas and facilitates students' critical thinking, learning models that provide opportunities for students to reason, actively learn in conveying ideas and argumentation or giving reasons.

From the findings of the data analysis results above, it is necessary to develop learning models that can improve students' reasoning so that students can have the ability to think critically and solve problems. In the process of learning, one constructs what has been learned and associates new experiences, phenomena, and facts into the structure of knowledge.

To achieve the expected skills in the 21st century, namely innovative learning on critical thinking skills and problem solving, making mathematical reasoning is very important to help students in arguing and making conclusions, it is necessary to develop learning models that are able to develop these abilities.

In this research, an advanced organizer model based on open ended approach will be developed to improve students' reasoning abilities in primary schools. With the development of an advanced organizer model based on the open ended approach, it is hoped that it can improve students' reasoning abilities because the model developed is oriented to how knowledge is managed, how the mind works in processing new information, giving students the opportunity to investigate various strategies and ways they believe in accordance with their abilities elaborating problems. Thus it has the potential to improve students' reasoning abilities in elementary school.

The results of preliminary research obtained a description of the implementation of the 2013 curriculum implementation, a description of the implementation of learning in elementary schools, the development of learning models expected of teachers in schools, a description of how learning should be implemented. Get recommendations about developing learning models to improve students' reasoning abilities. The results of this preliminary study form the basis for developing an advanced organizer learning model based on the open ended approach to improve student reasoning in elementary schools. From the results of the questionnaire distributed to teachers and principals obtained the following data:

1) The results of the analysis of the questionnaire on aspects of understanding the concept of the 2013 curriculum all respondents have understood and implemented the 2013 curriculum, respondents were able to explain about how the implementation of learning in the 2013 curriculum

2) In the aspect of the implementation of learning that takes place in the school respondents respond that learning is centered on students by applying a scientific approach to the dimensions of assessment of attitudes, knowledge, and skills. Need development, still minimal material, teachers and students still need to find references from other learning sources. The school has implemented the 2013 curriculum in accordance with the capabilities and conditions of the school, applying a student-centered learning model with a discovery learning model, problem base learning, and project base learning. Although in its implementation it has not been maximized. The model introduced in the 2013 curriculum is very helpful, but to improve the quality of learning it is necessary to develop good learning models, learning resources and media.

3) In the aspect of reasoning all respondents view that the reasoning ability of students is important to be improved, because in the 2013 curriculum learning is centered on students with the teacher as a facilitator in problem solving, so students are trained to be actively involved in solving problems. This is where student reasoning is needed, other respondents provide responses because students' reasoning helps in the development of mindset and makes it easier for students to understand the material in learning.

4) Then it is still related to students' reasoning abilities does the model introduced in the 2013 curriculum help? All respondents answered helped because the learning model used directed students to find their own answers through learning experiences so that reasoning in thinking increased. Another respondent revealed that the model introduced in the 2013 curriculum had helped in improving students' reasoning abilities, but needed to improve the quality of their learning.

5) Related to the development of the model, is it necessary to develop a learning model to improve students' reasoning? All respondents answered that the model development is very helpful for students to understand the learning material, so students can associate the material clearly, other respondents give reasons that science continues to develop so it is necessary to develop a model to improve students' abilities, other respondents stated the use of learning models that are varied and suitable for students still need to be developed.

6) In the aspect of development, with the question: what kind of model development do you expect? respondents respond: they can be applied to students well, are easy to implement but have a realistic impact on students' needs. Learning models that really provide opportunities for students to express ideas, ideas and opinions that train students to think critically and logically. Learning models that focus on students' full involvement in learning through a comprehensive and organized approach. Learning models that are able to improve students' reasoning ability, dare to think pleasant and easily realized for 
teachers. A learning model that is simple, fun, builds students' habits for thinking and reasoning, is active in learning. Learning models that are able to provide space for students to give ideas and find a concept. Learning models that train students to think systematically, structured and able to solve problems. Student-centered learning model, provides opportunities for students to manage knowledge to get new information, learning is done by asking questions that may have many correct answers; Students' activities must be open and must have a variety of thinking, giving students opportunities to discuss among students.

\section{Conclusions}

Based on the result of this study, the researchers conclude these points.

1. Understanding of Curriculum 2013 is good. The respondents understand and apply it on their class. They are able to explain how to apply it too.

2. The respondents suggest to activate students centre learning in classroom by applying Scientific Approach with Attitude, Knowledge, and Skill dimensions.

3. Teachers and students need to find other references.

4. On reasoning aspect, the respondents deal with enhancing students' skill. It is as mentioned on Curriculum 2013 that the learning process must be focused on students' centre learning while the teachers are the facilitators. The teachers support students' reasoning skill to solve problems.

5. Developing learning model must be done to enhance students' reasoning skill because it could help them to associate the lesson clearly.

6. Knowledge always develops. That is why development of learning model needs to do regularly to enhance students' skill.

7. Creating some new teaching models is needed.

\section{Acknowledgments}

Thank to Prof. Dr. Sunardi, M.Sc as a promoter, Prof. Drs. Gunarhadi, MA as co-promoter, Prof. Dr. Sri Anitah as co-promoter, and Fitri Yulianti, M.Pd. as the translator.

\section{REFERENCES}

[1] Baig, S \& Halai, A. (2006). Learning Mathematical Rules with Reasoning. Eurasia Journal of Mathematics, Science and Technology Education, 2(2), 15-33.

[2] Badan Pengembangan Sumber Daya Manusia Pendidikan dan Kebudayaan. (2013). Materi Pelatihan Guru
Implementasi Kurikulum 2013 SD Kelas I. Jakarta: Kementerian Pendidikan dan Kebudayaan.

[3] Badan Pengembangan Sumber Daya Manusia Pendidikan dan Kebudayaan. (2015). Materi Pelatihan Guru Implementasi Kurikulum 2013 SD Kelas VI. Jakarta: Kementerian Pendidikan dan Kebudayaan.

[4] Brodie, K. (2010). Teaching Mathematical Reasoning in Secondary School Classrooms. London: Springer.

[5] Creswell, J. W. (2012). Educational Research. Planning, conducting and evaluating quantitative and qualitative research. Fourth edition. Boston: Pearson.

[6] Creswell, J. W. (2016). Research Design Pendekatan Kualitatif, Kuantitatif, dan Mixed. Yogyakarta: Pustaka Pelajar.

[7] Dell'Ollio, J., M., Donk, T. 2007. Models of Teaching: Connecting Student Learning with Standartds. London: SAGE Publication.

[8] Fatah, A., Suryadi, D., Sabandar, J., \& Turmudi. (2016). Open-Ended Approach: An Effort in Cultivating Students' Mathematical Creative Thinking Ability and Self-Esteem in Mathematics. Journal on Mathematics Education, 7(1), 9-18.

[9] Fisher, A. (2009). Berpikir Kritis Sebuah Pengantar. Jakarta: Erlangga.

[10] Borg, W., R., Gall, M., D. 1983. Educational Research an Introduction Fourth Edition. New York: Longman.

[11] Gall, M. D., Gall, J. P. \& Borg, W. (2007). Educational Research an Introduction. Eighth edition. New York: Pearson.

[12] Kemendikbud. (2014). Peraturan menteri pendidikan dan kebudayaan nomor 103 tentang Pembelajaran Pada Pendidikan Dasar dan Menengah. Jakarta: Kementerian Pendidikan dan Kebudayaan.

[13] Kemendikbud. (2016). Peraturan menteri pendidikan dan kebudayaan nomor 22 tentang Standar Proses Pendidikan Dasar dan Menengah. Jakarta: Kementerian Pendidikan dan Kebudayaan.

[14] Kroll, L. R. (2016). Constructing constructivism: How student-teachers construct ideas of Development, knowledge, laring, And teaching. Journals Teachers and Teaching: Theory and Practive, 10(2). 1470-1478. Download by Gazi University, date: 10 January 2016, At: 22:38.

[15] Kusumawardani, D. R. Wardono, \& Kartono. (2018). Pentingnya Penalaran Matematika dalam Meningkatkan Kemampuan Literasi Matematika. Prisma 1(2018), Proceding. Prisma 1,Seminar Nasional Matematika: Unnes.

[16] Mayer, R. E. (2010). Rote Versus Meaningful Learning. Journal Theory into Practice, 41(4), 226-232. Published online: 24 Jun 2010.

[17] Namira, Z. B., Kusumo, E., \& Prasetya, A. T. (2014). Keefektifan strategi metakognitif berbantu advance organizer untuk meningkatkan hasil belajar kimia siswa. Jurnal Inovasi Pendidikan Kimia. 8(1), 1271-1280.

[18] National Council Teacher Mathematics. 2000. Principles 
and Standards for School Mathematics. Reston: NCTM.

[19] Novak, J. D. (2002). Meaningful Learning: The Essential Factor for Conceptual Change in Limited bor Inappropriate Propositional Hierarchies Leading Do Empowerment of Learners. Journal Learning, received 14 September 2000; revised 17 December 2001; accepted 14 January 2002.

[20] Pamungkas, T., Alamsyah, \& Turmudi. (2016). Kemampuan Berpikir Kritis dan Kreatif serta Self-Esteem Matematis Siswa melalui Model Advance Organizer. Jurnal Pendidikan Matematika, 1(2), 119-128.

[21] Parjayanti, A. D., \& Wardono. (2013). studi komparasi model pembelajaran antara inkuiri dan advance organizer untuk penalaran matematis. Jurnal Kreano, 4(1), 64-72.

[22] Pratitis, I \& Binadja, A. (2014). Penerapan Model Pembelajaran Advance Organizer Bervisi Sets terhadap Peningkatan Penguasaan Konsep Kimia. Jurnal Inovasi Pendidikan Kimia, 8(2), 1370-1379.

[23] Putra, F. G., dkk. (2018). The Implementation of Advance Organizer Model on Mathematical Communication Skills in terms of Learning Motivation. Tadris: Journal of Education and Teaching Training, 3(1), 41-46.

[24] Rahayu, S., Widodo, A. W., \& Supartono. (2010). Pengembangan Model Pembelajaran Advance Organizer Untuk Meningkatkan Aktivitas Dan Hasil Belajar Siswa. Jurnal Inovasi Pendidikan Kimia, 4(1), 497-505.

[25] Sajadi, M., Amiripour, P. \&Malkhalifeh, M. R. (2013). The Examining Mathematical Word Problems Solving Ability under Efficient Representation Aspect. Journals mathematics Education Trends and Research, Vol. 2013. ISPACS International Scientific Publications and Consulting Services.

[26] Schunk, D. H. (2012). Learning Theories an Educational Perspective. Boston: Pearson.

[27] Setyosari, P. (2012). Metode Penelitian Pendidikan dan Pengembangan. Jakarta: Kencana Prenada Media Group.

[28] Shabania, N., Mardiati, Y., Sofyan, A. (2015). Pengaruh Pembelajaran Model Advance Organizer Terhadap Hasil Belajar Biologi Siswa Pada Konsep Protista. Jurnal Edusains, 7(1), 70-76.

[29] Shadiq, F. (2004). Penalaran, Pemecahan Masalah dan Komunikasi dalam pembelajaran matematika. Yogyakarta: Departemen Pendidikan Nasional Pusat Pengembangan Penataran guru (PPPG) Matematika.

[30] Shimada, S. (2005). The Open Ended Approach: A New Proposal for Teaching Mathematics. Virginia: National Council of Teacher of Mathematics.

[31] Sukmadinata, N. S. (2012). Metode Penelitian Pendidikan. Bandung: Remaja Rosdakarya.

[32] Suwandi, S., dkk (2016). Pedoman Tesis dan Disertasi Pascasarjana Kependidikan Fakultas Keguruan dan Ilmu Pendidikan. Surakarta: UNS Press

[33] Tasiwan, Nugroho, \& Hartono. (2014). Pengaruh Advance Organizer Berbasis Proyek Terhadap Kemampuan Analisis - Sintesis Siswa. Jurnal Pendidikan Fisika Indonesia,10(1), 1-8.
[34] -------. (2014). Analisis Tingkat Motivasi Siswa Dalam Pembelajaran IPA Model Advance Organizer Berbasis Proyek. Jurnal Pendidikan IPA Indonesia, 3(1), 43-50.

[35] Triwibowo, Z. N.K. Dwidayani, \& Sugiman. (2017). Analysis of Mathematical Creative Thinking Ability Viewed from Students Learning Styles in Seventh Grader Through Treffinger Learning Model with Open-Ended Approach. Unnes Journal of Mathematics Education, 6 (3), 391-399. 